\title{
FEMINISM PORTRAYED IN GRETA GERWIG'S MOVIE LITTLE WOMEN; ANALYSIS IN MODERN ERA
}

\author{
Nurmala Dewi, \\ nurmala.nmd@bsi.ac.id \\ Universitas Bina Sarana Informatika \\ Tatia Ishlah Medina \\ tatia2429a@gmail.com \\ Universitas Bina Sarana Informatika
}

\begin{abstract}
This paper discussed feminism in the Little Women movie directed by Greta Gerwig in 2019. This movie is adapted from Louisa May Alcott's novel which was written initially in 1868. This study aimed to find out how feminism is described through the leading character. The other objective is to search the types of feminism on the main character refers to Tong and Botts's theory. The writer used descriptive qualitative methods which content analysis of the movie. All data is presented in the form of words and sentences and used library research as a way to collect data by reading and selecting quotations from the Little Women movie. As the result, it is found that there are five types of feminism: Liberal Feminism type, Marxist Feminism and Socialist type, Radical libertarian Feminism type, Psychoanalytic Feminism type, and Postmodern Feminism type. Besides the types of feminism, the discussions depicted feminism impact to the characters among women and send the views and values in women personal life with connected to the relationship of family matters as well.
\end{abstract}

Keywords: Feminism, Little Women, Types of Feminism

\section{INTRODUCTION}

Literature is the work of verbal and written creation that concern to the author's intentions which is referred to be an art form. Basically, literature has three subjects; drama, poetry, and prose. The Prose is divided into two things; they are fiction prose and nonfiction prose. Fiction itself refers to literature created from the 
imagination. Mysteries, science fiction, romance, crime thrillers are all fiction genres. While, nonfiction refers to literature based on fact, including biography, business, cooking, health, languages, religion, art, and music, history, etc.

A literary work can be analyzed in several aspects; one of them connected to human life is through the approach of literary psychology. Psychology Literature is an approach that considers the psychological aspects and concerns the inner human. Wellek and Warren (1949: 81) said in their book Theory of Literature "Psychology can enter to literature by studying the psychology of the writer, psychology of the character, and also the psychology of the reader." So, it can be correlated with each other and be a baseline of the writer in creating their works.

The movie is one of the categorizations in literature alongside novels, poems and plays. Various themes can be raised for a movie. One theme in women's life is feminism, the topic that is analyzed in this paper. The source of analysis in this study is The Little Women movie directed by Greta Gerwig. There is no shortage of adaptations of Louisa May Alcott's novel Little Women which was written initially in 1868, but Greta Gerwig's 2019 film is easily impactful for modern audiences. How Greta Gerwig adapted a-150-year-old-text into the situation now, is quite challenging. Little Women has always been a relatable story about female experiences, but its relevance has never been more apparent than it is in Gerwig's retelling. The film maintains the historical charm of the novel but brings contemporary values to the narrative. It brings the feminist undertones of the original story to the forefront, balancing its setting with commentary about gender that is still relevant.

In the past, women were always under pressure and excessive social expectations. The gender between men's and women's' roles in society is different. The specific characters embed in their personality are contrast as well. Men are masculine, assertive, strong, logical while women are feminine, gentle, obedient, and sensitive. Old tradition always believes that women can only be a housewife who always handles the household such as cooking, sweeping, washing, taking care of her husband and children. This is the kind of perception that exists in our society. Even today in the modern era, there are still 
kinds of those beliefs in some parts of the earth.

Feminism firstly arouses as a women's movement in demanding equal rights in the late 19th and early 20th centuries that pushed for political equality. The second wave, in the 1960s and 70s, demanded legal and professional equality and the third wave, in the past couple of decades, has concerned for social equality. The feminism movement is committed by women to reject everything marginalized, subordinated, and demeaned by dominant cultures, both in political, economic, and other social life. Since most societies give privilege to men as a group of powerful people with the assumption that men are more competent, good orientation, strong, active, competitive, and confident than women. This condition is unfair for women and portrayed gender discrimination. It happens from one generation to the next time until they realized their injustice. So that, it encouraged the emergence of a belief called feminism. This feminism movement arises because of a wanting impulse to equalize the rights between men and women who had been as if women are not respected in taking opportunities and decisions within life. There such thinking seems to have been entrenched so women should be struggling to show their existence in the eyes of the world.

Nowadays, the conditions have been changing. The women have the same authority to do something like men doing in economic, social, and political. Feminism urges for the full integration of women into society, demanding women's equal rights, equal work, equal pay, equal status and treatments in public and private relations. This movement has been grown and continued to improve women through the activities campaigned their views to the world. For example, a campaign through social media namely Twitter, using the hashtag \#YesAllWomen which voiced the seriousness of the issue of violence against women. Various tweets told the personal stories of Twitter users who have experienced or witnessed the women issues. Through this media, it also provides a variety of articles and professional discussions concern with women's life.

Definition of feminism itself as described by Hannam (2007) is "Feminism is a cultural as well as a political movement. It changes the way women think and feel and affect how women and men live their lives and interpret the world. For this reason, it has provoked lively debates and fierce antagonisms that have 
continued to the present day". So, feminism considers an imbalance between men and women. Because the position and role of women are considered lower than men, women are considered to only be able to depend on men. Therefore, women believe that this condition can change by emphasizing the independence of the woman herself. While Hooks's definition (2000) tends to physical treatment that women faced, "Feminism is a movement to end sexism, sexist exploitation, and oppression". This indicates women hope for having value in society and getting the same equality as men without exploitation and oppression. Feminism opposes the degrading treatment of women by men in family and society. It raises issues relating to autonomy or personal freedom, by referring injustice between the sexes.

More deeply to the characteristic of feminism, Tong and Botts (2018) categorized various theories of feminism into ten types: Liberal; Radical; Marxist/Socialist; Women of Color; Global, Postcolonial, and Transnational; Psychoanalytic; Care Focused; Ecofeminism; Postmodern; and the last is Third Wave. Liberal feminism focuses on the elimination of inequality between women and men in legal, political, social, workplace and educational settings. Radical feminism has a trait between biologically determined behaviours and culturally determined behaviours that already exist, to free men and women as much as possible from their previously narrow gender roles. While women of colour is a site of multiple forms of oppression in discrimination on the bases of race and gender. It is different from Global feminism that focuses on women's health, education and welfare issues, with a great emphasis on human and women's rights. Postcolonial feminism refers to economic, social and political issues, emphasizing that the oppression of women as members of formerly colonized societies. Meanwhile, Transnational feminism tends to the relationship between nationality, race, gender, sexuality and economic exploitation in the context of the spread of capitalism throughout the world. And for Psychoanalytic feminism argues that the basic explanation for the way women act comes from within their souls, specifically, from the way they think about themselves as women. The last, CareFocused feminism emphasizes aspects of children's development in particular, namely their psychomoral development. 
These theories become part of the baseline to see how feminism applied to the Little Women movie as a resource of analysis of this study. As the aim of the study, the writer wanted to analyze the

\section{METHODS}

The method of study is library research and descriptive qualitative research. According to Polit and Beck, "Qualitative description (QD) is a label used in qualitative research for studies that are descriptive in nature" (Kim et al., 2016). This research method is often used to analyze the activities and phenomena that exist in society. In analyzing, all the data are presented in the form of words and sentences. The theme that become the main discussion in this paper is concerned to the depiction of feminism portrayed in the main character and its types. The first step of analyzing, the writer read any literatures related to the topic would be discussed. Then collected the materials which support feminism theme and categorized it based on the theory. The writer divided data into two parts, they are primary data and secondary data. The primary data can be reflection of feminism in Little Women Movie and elaborated it in which types of feminism applied in the movie that written originally in past decades but released in this modern era.

derived from the Little Women movie as the main data. The secondary data is obtained from books, articles of journals, or other sources of materials related to the topic. To analyze data, the writer watched the movie several times to get comprehension and connected it to the theories of feminism. Then, the writer found some information in books, journals, and articles related to feminism made interpretations based on the movie seen before. After that, the writer selected and picked the data, which are the words, phrases, and sentences on the dialogue of the movie. Data analysis was applied when all the data from the movie was collected. Finally, the writer analyzed the data focusing on the feminism aspect and categorized it into several types based on the theory. 


\section{RESULTS AND DISCUSSION}

\subsection{Feminism in the Movie}

Little Women is an epic movie which has Civil War in 1800s as its background. It tells about March family who lived in Concord, England. March who was told joining the war in the first story has four daughters with different characteristics. The girls named Margaret, Josephine, Elizabeth, and Amy. In Little Women movie, although the story is set in the midnineteenth century, the March daughters' trials, burdens, and aspirations resonate with a modern era and apply to audiences' live. In the story, every girl has their own story: Meg struggles with the sacrifices that come with raising a family; Beth is kindness is unwavering in the face of personal struggle; Amy's ambition to leave her mark is a force to be reckoned with; Jo fights for her voice to be heard as a writer in a discipline dominated by men. Jo's frustration at being told what a woman can and cannot do is tangible. At that time if you do not want to be a writer or a painter and you will never travel to New York or Paris like Jo and Amy. Their battles and triumphs may seem to adhere to their life. It is all the more powerful because it shows an experience that is still common happen among women nowadays. But whatever conditions, they are still strong to support each other and think that everyone is important.

As common girls growing, they frequently make mistakes. They fight, make irrational decisions, and question who they are and what they stand for. They disagree with the idea of the ideal female protagonist who must effortlessly balance personal aspirations with the societal burden of being a woman. The March's daughters represent realistic women who are long overdue representation onscreen. Meg, Jo, Amy, and Beth are not polite, reserved, and downtrodden; they are alternatingly angry, burdened, giddy, and determined.

Little Women has been adapted in various versions such as miniseries, operas and movies. When the first movie released in 1994, there was still a lot of oppositions against the idea that women could be independent. The women were difficult in compromising their choices. if they had careers, they would leave their families behind. This movie adaptation was slightly soft and tame which shown the interpretation of the story at that time; Marmee, the girls' mother, lectured on the negative health effects of corsets and the benefits of girls' education. Jo made the case for women's right to vote, which does not exist in the original novel story. But the film still ends on the love scene and happy ending as many

JEE (Journal of English Education) Vol. 6 No. 2, December 2020

http://journal.upp.ac.id/index.php/JEE

P-ISSN:2459-9719, E-ISSN 2597-7091

DOL: https://doi.org/10.30606/jee 
people expected in any kinds of the story; Professor Bhaer, whom Jo ultimately marries, who takes her book to the publisher. So, this action was not from Jo but Professor Bhaer, making him as the instrument of her success. In other words, the girls' choices are delivered as an individual, not structural.

Twenty-five years later, when the second movie released in 2019 , the narration is a bit change and the end of the story as well that Jo does not marry Professor Bhaer, For the interpretation, it seems that the characters take more than one dimensions. Meg's story struggles with her family life and still continues as she raises her twins and buys nice things she cannot afford. Beth fights with her ill and destined for death; she is depicted as an artist in her own right. Amy, the bratty younger sister, who has long views and develops into a young woman whose clarity in her ambition is enviable. So, in this version gives illustrations on the real facts of life. People have caught up in the sense of that a girl or a woman who speaks her mind and become a pleased character is not always delighted and cheer up the life. But at the end of the film, at least give more happiness to the audience which presents Jo and her mother gets the satisfaction of watching Jo's book as to be born with its pages bound and leather stamped by the printer.
Little Women is a beautiful story about family and love, the challenges and sacrifices, the creativity and imagination that comes from childhood to adult. This film is the invisible sound of feminism and it is a way Gerwic's interpretation of women's adaptations in this new era. In brief, Gerwig's Little Women celebrates women of all different forms, not just the passionate and outspoken Jos of the world.

\subsection{Types of Feminism}

Analyzing the feminism trait in their characters, the writer also elaborated the types of feminism which is the main discussion on this paper. The writer identified the data on the movie and analyzed it based on the theory which refers to Tong and Botts theory that compiles feminism in detail and categorized it into several types. The writer found five types of feminism; they are Liberal Feminism, Marxis and Socialist Feminism, Radical Libertarian Feminism, Psychoanalytic Feminism, and Postmodern Feminism which will be explained below.

\section{Liberal Feminism}

Liberal feminism focuses on the elimination of inequality between women and men in the legal, political, social, workplace and educational settings. Liberal feminism is 
characterized by a focus on equality. It argues that men and women should be treated equally. If women are given the same educational, occupational, and political opportunities as men, they will realize their true potential and no longer be subordinate to men. It can be said that liberal feminism was a struggle for women for civil service and economic opportunities. There are two data reflected in this category.

Jo
Friedrich : "My students need me"
Jo
$\begin{aligned} & \text { : Money is the end and aim of my } \\ & \text { mercenary existence" }\end{aligned}$
Friedrich : "No one gets ink stains like yours
just out of a desire for money"
Jo "Well my sister Amy is in Paris,
and until she marries someone
obscenely wealthy, it's up to me
to keep up the family afloat"

This dialogue is between Jo March and Friedrich Bhaer in their boarding house, in New York. From the scene, Jo was preparing to bring a book and went to the place she was teaching, but Friedrich continued to talk to Jo. The scene shows that women can play a role in the work environment as same as men. Based on the dialogue, Friedrich said "always working" implies that women should not work in the workplace, but the role of women should be in the domestic environment. However, Jo wanted to end the oppression that women are only suited to the domestic environment. Women do not have to always be in the domestic environment and women deserve to get the opportunity to work in society. A woman feels able to make choices and decisions for her life. The decision is not only through marriage to a rich person, but the decision can be working in society.

The above scene shows the struggle of women in the economy to get the opportunity in terms of work just like men. Men assume that women are not competent at work. Based on the theory of feminism by Tong and Botts, this scene is categorized into a liberal feminism type. Liberal feminism focuses on gender equality and equal opportunities between women and men.

The next dialogue between Jo and Mr. Dashwood also supports this type of feminism. Jo : II want ten percent of royalties."
Mr. Dashwood : "Five point five percent and that is very generous."
Jo : "Nine percent."
Mr. Dashwood : "Six percent -- and that's it." Jo : "If I'm going to sell my heroine into marriage for money, I might as well get some of it."

This scene shows a dialogue between Jo March and Mr. Dashwood who negotiated the royalties of Jo's book. Jo stated that she wanted ten percent for royalties, but Mr. Dashwood offered a lower royalty of only five percent, and for him, it was a generous thing. The publisher should have given female writers royalties as much as they gave to male writers. Jo as a female writer who sells her work for money should get more royalties. Jo's action in the scene shows how she was trying to get the royalties she deserves as a writer. Jo tried to equalize the royalties of female writers as same as male writers. 
All of the scenes above show that in the economy women are considered to be incompetent in terms of work because gender equality has not been achieved. Men believe that women cannot risk being responsible and making decisions independently, because of that women get lower salaries. Liberal feminism believes that men and women should be treated equally, and women get the same social, educational, employment, economic, and political opportunities as men. This type also focuses on the equality between men and women, they should have the same position without facing discrimination.

\section{Marxist and Socialist Feminism}

Marxist and socialist feminism is a struggle to demand right and justice, abolish the system of ownership. That means Marxist feminists are concerned with the division of labour making women remain in the domestic sphere and men in the workplace. Socialist feminists move to rely on the class as the only category to understand the subordination of women to men. The data shown to this type is below.

Aunt March : You mind yourself, dearie, one
day you'll need me and you'll
wish you had behaved better"
:"Thankyou, Aunt March, for your
employment and many
kindnesses, but I intend to make
my own way in the world." Aunt
March: "No one makes their own
way, not really, least of all a
woman. You'll need to marry
well."

The dialogue above is when Jo visited Aunt March's house. It shows that Jo wanted to be free to determine her life in the way she wants. She thinks that women have the right to make their own choices without depending on others. Aunt March considered Jo must marry someone rich; she is not sure that Jo can open her way to get her dream because she thinks women can only rely on men. But, Jo was sure of the path she chooses and would not accept oppression because of the capitalist system. Jo did not want to get married because she feels she does not want to be the private property of her husband later and she believes that women can be independent women.

This dialogue refers to a type of Marxist and Socialist feminism, which ends the oppression of women caused by the system of property rights of men. Marxist and socialist feminists focus on the division of labour between women and men, so that women are not always in the domestic sphere, such as getting married and becoming a wife, then taking care of children, and then having the opportunity to work at the workplace. Marxist and socialist feminism rely on their class to clarify how women are oppressed in a capitalist country. 


\section{Radical-Libertarian Feminism}

Radical feminism is the struggle of women in ending women's oppression based on the sex and gender system. Radical feminism believes that actual gender or gender equality is not possible in a patriarchal system. This system is full of oppressive patriarchal norms, assumptions, and institutions, true emancipatory reform is only possible through radical rearrangement of society that eliminates male supremacy. According to Tong and Botts, radical feminism is split into two general camps, one of which is radical-libertarian feminism. And this data below describes radical-libertarian feminism.

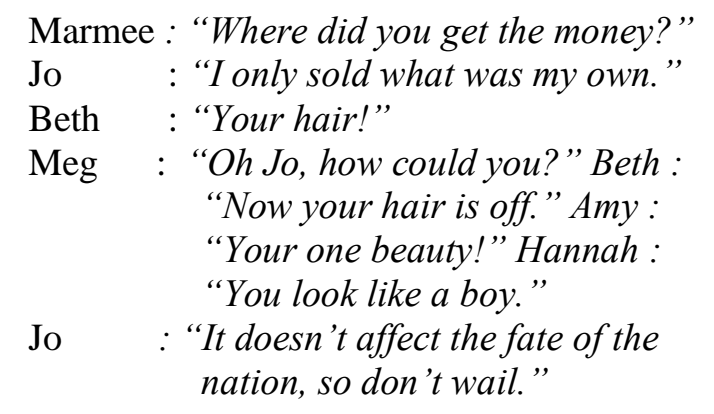

This scene is at the March family home when all were busy preparing for the departure of Marmee (March's mother). She prepared to visit her husband who was sick when volunteering for the civil war. Jo appeared in the middle of preparations for her mother's departure with twenty-five dollars as train fare. Jo let her hair cut to sell and earn money as the train fare for the mother. In that era, cutting hair was taboo for women, but Jo did not care about the gender standards that exist at that time. Although the people around her were surprised and thought of her as a boy, Jo did it of her own free will. The dialogue explained that Jo sells her long hair because of her own decision, other people have no right to prohibit it for any reasons. Jo showed the masculine side of the way she cuts her hair which is short as a man's. In that era, women usually do not look like men. Women who are shown in that era are feminine and elegant in their behaviour and appearance.

This type of radical libertarian feminism encouraged women to become androgynous that is, to embody both (good) masculine and (good) feminine characteristics or, more controversially, masculine and feminine characteristics, good or bad, to their liking. Radical-libertarian feminists claimed that exclusively feminine gender identity is likely to limit women's development as fully human persons.

\section{Psychoanalytic Feminism}

Psychoanalytic feminism is the way women act originated or rooted in the female soul, especially in the way women think about themselves as women. This reflects in Jo's statement below when she was at March's house:

Jo : "Women have minds and souls as well as hearts, ambition and talent as well as beauty and I'm sick of being told that love is all a woman is fit for."

Jo cried and tried to explain herself about women's thoughts. The dialogue above illustrates how Jo felt so sick with what people say about women that is only suitable for 
romance. She thinks that women have ambitions and talents to make them have rights and equality with men in society; the way women act and think comes from their souls. But she felt that she has no rights and equality as a woman.

This data can be categorized into psychoanalytic feminism type. Psychoanalytic feminists argue that the basic explanation for the way women act comes from within their souls, specifically, from the way they think about themselves as women. Psychoanalytic feminists claim that gender identity, gender injustice, is rooted in a series of experiences of childhood and early childhood. These same experiences are the cause of society's privileging things "masculine" over things "feminine". In psychoanalytic feminist estimates the causes of individuals who see themselves in masculine or feminine terms, consider themselves to be boys or girls.

\section{Postmodern Feminism}

Postmodern feminists invite every woman who reflects on their writing as a form of the voicing of various types of women's inequality. This challenges women to write for their beliefs and voiced the views of the world. Postmodern feminism is the women's struggle through writing to obtain feminist goals inequality and rights without pressure.

This data without dialogue (1:52:281:54:20) whereas the scene is in March house at Jo and Meg's room. She was writing in her room only lighted by a candle. She was reconnected with her childhood, and out of the depths of despair has found hope and inspiration. It illustrates Jo's writing process which eventually produced a book to publish. After rejected by the publisher frequently, this time the writing was approved by the publisher and she was able to print her book. Writing is Jo's desire; through her writings, Jo hoped to inspire women to be able to change the way women think, talk, and act. Putting down their words in writing, women have voice, identity, and media as men have in expressing themselves.

The Little Women movie was set in 1861-1871, that year there was no word "feminism" or even the feminist movement, therefore women at that time naturally have their feminist views. Although the story was produced many years ago, the basic aspect of feminism that alludes to this movie is still relevant nowadays. This movie also indirectly sends messages which can inspire the audiences whereas women have the right and decision to choose what they want to live. It can be seen from this movie through Jo's decision to go to New York and start her life by becoming a great writer and teacher. It also gives the message to people that perseverance is an important aspect to pursue the goal and never give up to achieve it. It demonstrates in the movie where Jo is consistent in writing. Even after her 35 stories were often rejected by publishers, Jo continued to write with a new story. Helping each other especially among members of a family is also a value sending in this movie. As shown in Jo's character that always helps her sister and her neighbours who are in a difficult situation. Every 
burdens and trouble would be handled together which made it easier to resolve and reflect the

important person each of them.

\section{CONCLUSION}

The movement of feminism is still around of women's experiences since many years ago. Because these issues are common to appear in women life, it often becomes a topic in literary works such as a movie. The Little Women is a movie telling about the feminism aspects of women to reflect her identity. It has several versions of the movie, and the last version directed by Greta Gerwich, published in 2019. Although Little Women movie is set feminism in the 19th century the views are still applied in the modern era which presents a different perspective from the original ones.

In analyzing this movie, it indicated that the feminist views have embedded particularly to the main character of Jo. Jo's perspective can change how women achieve their career and balance with family matters. She shows that women would be able to voice various kinds of inequalities and oppression, would be able to change the way of thinking, speaking, and acting in which getting the same equal with the men. Besides discussing the feminism aspect depicted in the movie, the writer also found five types of feminism based on Tong and Botts theory. They are Liberal Feminism, Marxist and Socialist Feminism, Radical-Libertarian Feminism, Psychoanalytic Feminism, and the Postmodern Feminism. These all aspects of feminism have embedded on the main character in executing his decision of life. All and all, this movie tells how women's roles in facing many aspects of life. So, this movie can be a good reference by anyone, especially a woman who wants to actualize herself without putting down the other side of her identity.

\section{REFERENCES}

Hannam, J. (2007). Feminism (Short Histories of Big Ideas). In Great Britain.

Hooks, B. (2000). Feminism is for Everybody. In South End Press. https://doi.org/10.1016/S0140-6736(19)30239-9

Kim, H., Sefcik, J. S., and Bradway, C. (2016). Characteristics of Qualitative Descriptive Studies : A Systematic Review. Wiley Online Library (Wileyonlinelibrary.Com). https://doi.org/10.1002/nur.21768

Lapandja, F. K. ., Usman, S., and Muhsin. (2016). A Study of Main Character And Plot In Ahmad Fuadi's "Negeri 5 Menara." E-Journal of English Language Teaching Society, $4(1), 1-13$.

Mangan, L. (2019). The Feminism Book. In Dorling Kindersley, derived from : 
https://doi.org/10.1017/CBO9781107415324.004

Rachman, F., and Safrudi, I. (2014). Feminism of Alice Paul in Iron Angels Movie. ABA BSI Jakarta, 6(2), 11.

Rainsford, D. (2014). Studying literature in English: An introduction. In Studying Literature in English: An Introduction. https://doi.org/10.4324/9780203483824

Tarvainen, J., Westman, S., and Oittinen, P. (2015). The way films feel: Aesthetic Features and Mood in film. Psychology of Aesthetics, Creativity, and the Arts, 9(3), 254-265. https://doi.org/10.1037/a0039432

Tong, R., and Botts, T. F. (2018). Feminist Thought (Vol. 53). Westview Press. https://doi.org/10.1017/CBO9781107415324.004

Wellek, Rene and Warren, Austin. (1949). Theory of Literature. New York: Harcourt, Brace and Company, Inc

Weston, J. (2003). The Film Director's Intuition: Script Analysis and Rehearsal Techniques. Michael Wiese Productions, 345.

JEE (Journal of English Education) Vol. 6 No. 2, December 2020

http://journal.upp.ac.id/index.php/JEE

P-ISSN:2459-9719, E-ISSN 2597-7091

DOL: https://doi.org/10.30606/jee 